\section{An Attempt to demonstrate Autologous Recognition of Malignant Cells by an in vivo System}

IT is known that malignant cells can be removed from the circulation and disposed of by unknown mechanisms. An attempt was made to demonstrate autologous sensitization to ectopically placed tissues ${ }^{1}$, and so attention was directed to the possibility of autologous recognition of malignant cells.

Fibrosarcomas were induced in Sheffield strain Wistar rats by the subcutaneous injection of $0.05 \mathrm{~g} 20$-methylcholanthrene into the anterior abdominal wall of the host animals.

When a tumour had grown to about the size of a hazel nut it was oxcised, and a small portion of the tumour was enclosed in a 'Millipore' chamber of $0.45 \mu$ porosity which was inserted into the peritoneal cavity of each host animal. The main bulk of the tumour was then kept at $-20^{\circ} \mathrm{C}$ until needed.

As Dempster ${ }^{2}$ showed that a host has to be sensitized for a minimum of 8 days with a skin graft before a second set response can be obtained to a further skin graft, the rats were kept alive for between 8 and 13 days before they were killed. Cell suspensions were made, by the method of Branster and Morton ${ }^{3}$, of both the spleen of the host and the stored tumour. A cell suspension was made of a normal spleen from the same strain of rat. Cell counts were done, and the sensitized and normal spleen suspensions were adjusted to equality. Four to one volumes of spleen to tumour cell suspensions were injected subcutaneously into one flank of guinea pigs, the other, control, flank receiving similar quantities of normal splean cell suspension and tumour cells.

The guinea pigs were killed, and the flares under the skin were examined and photographed 3-4 days later. Flares were assessed by the size and intensity of reddening on the under surface of the skin at the site of the injoction, and it was found that flares were predominantly larger in the experimental as compared with the control side. Owing to the diversity of shapes it was not possible to measure them (Table l).

\section{Experimental side flare larger Control side flare larger \\ Autologous tumour-sensitized Normal spleen and tumour $\begin{array}{ccc}\text { spleen and tumour cells } & \text { cells } & 2 / 43\end{array}$ \\ Flare equal both sides Spleens had been sensitized by charged 'Millipore' chambers intra- peritoneally for between 8 and 13 days.}

In case this was only a non-specific reactivity which was being demonstrated, a further series of experiments was designed. Here a rat splean was sensitized by intraperitoneal implantation of a 'Millipore' chamber charged with a piece of autologous 20-methylcholanthrene-induced fibrosarcoma as before, and tested in the guinea pig with a tumour cell suspension. In this series, however, the control side was the autologous tumour-sensitized spleen cell suspension (the same as in the experimental side) and the antigen a cell suspension of autologous liver (Table 2).

$\begin{array}{ccc}\text { Experimental side flare larger } & \begin{array}{c}\text { Table 2 } \\ \text { Control side flare larger }\end{array} & \begin{array}{c}\text { Flare equal } \\ \text { both sides }\end{array} \\ \begin{array}{c}\text { Autologous tumour-sensitized } \\ \text { spleen and tumour cells }\end{array} & \begin{array}{c}\text { Autologous tumour-sensitized } \\ \text { spleen and autologous liver } \\ 24 / 34\end{array} & 7 / 34\end{array}$

In case the 'Millipore' chamber itself was activating the spleen, an empty 'Millipore' chamber was inserted intraperitoneally in a rat for 12 days. A piece of autologous liver tissue enclosed in a 'Millipore' chamber was placed intraperitoneally in another rat for a similar number of days. Cell suspensions were made of both spleens as before, and a cell suspension of liver was used as the antigen in both guinea pig flanks (Table 3).

\begin{tabular}{|c|c|c|}
\hline Experimental side flare larger & $\begin{array}{l}\text { Table } 3 \\
\text { Control side flare larger }\end{array}$ & Flare equal \\
\hline $\begin{array}{c}\text { Autologous liver-sensitized } \\
\text { spleen and liver cells } \\
3 / 4\end{array}$ & $\begin{array}{c}\text { Empty 'Millipore'-sensitized } \\
\text { spleen and liver cells } \\
1 / 4\end{array}$ & - \\
\hline
\end{tabular}

Tho 'Millipore' chamber does not appear, therefore, to activate the spleon. There is a predominantly larger flare in the side of the guinea pig which received a sub. cutaneous injection of autologous (chemically induced) fibrosarcoma cell suspension and autologous spleen cells (which had been sensitized by a piece of the autologous tumour in a 'Millipore' chamber) than there is in the other (control) side of the guinea pig which received the same autologous tumour-sensitized spleen suspension and a suspension of autologous liver. This appears to be a specific sensitization of the spleen to autologous tumour cells.

Such a recognition by autologous tissues presupposes some antigenic alteration of ectopically placed tissues ${ }^{4,5}$.

We know that malignant cells have lost a lipoprotein constituent ${ }^{6}$, and we believe that this loss is associated with the loss of TSA which also occurs in carcinogene$\operatorname{sis}^{7-10}$. Moreover, we also know that the malignant cell behaves differently from the normal cell in many ways, and that it has a higher negative surface charge than the normal cell ${ }^{11}$. Anthony and Parsons ${ }^{12}$ have found, using a Coombs consumption test, a globulin on the surface of tumour cells from both animals and human beings which was not found on the corresponding normal tissues, and others also have shown that malignant cells have an avidity for plasma proteins which is not associated with their rate of growth ${ }^{13}$.

Billingham et al.14 have shown by adoptive immunity that fixed and circulating cells of the immune mechanism can mediate different types of responses, and Goswami ${ }^{15}$ demonstrated an increased eosinophile response to heterologous fixed tissue cells which is not obtained using circulating heterologous leucocytes. It may be surmised therefore that fixed and mobile cells of the immune system are capable of different methods of action.

The mechanism of the reactivity in the guinea pig has not been investigated as it was felt that the essential problem is whether or not a soluble antigen is coming from the 'Millipore' implant which is capable of, in some way, sensitizing the autologous spleen to the tumour cells.

It is believed that in the early stages of tumour growth part of the immune mechanism of the host animal is capable of recognizing and responding to an alteration in function, if not in structure, of the malignant cell, and that this can, in some cases, be demonstrated by PCA in guinea. pigs.

\section{Mary R. Anderson}

Department of

Experimental Pathology and Cancer Research, School of Medicine,

Leeds, 2.

${ }^{1}$ Anderson, M. R., Nature, 189, 712 (1963).

${ }^{2}$ Dempster, W. J., Calnan, J. S., and Kulatilake, A. E., Brit. Med. J., i, 23 (1963).

${ }^{3}$ Branster, M. V., and Morton, R. K., Nature, 180, 1283 (1957).

4 Green, H. N., Cancer, edit. by Raven, R. W., 3, 1 (Butterworth, London).

${ }^{5}$ Anderson, M. R., and Green, H. N., Nature, 198, 861 (1963).

- Westrop, J. W, and Green, H. N., Nature, 186, 350 (1960).

${ }^{7}$ Green, H. N., Ann. N.Y. Acad. Sci., 68, 268 (1937).

* Nairn, R. C., Richmond, H. G.. McEntegart, M. G.. and Fothergill, J. E. Brit. Med. J., ii, 1385 (1960). - Nairn, R. C., Fothergill, J. E., McEntegart, M. G., and Richmond, H. G.
Brit. Med. J., i1, 1791 (1962).

${ }^{10}$ Baldwin, R. W., Brit. Assoc. Cancer Res., Leeds (1963).

"Abercrombie, M., and Ambrose, E. J., Cancer Res., 22, i, 825 (1962).

${ }^{12}$ Anthony, H. M., and Parsons, M., Dept. Exp. Path. and Cancer Res. Medical School, Leeds (personal communication).

12 Ghose, T., Nairn, R. C., and Fothergill, J. E., Nature, 186, 1308 (1862).

14 Billingham, R. E., Brent, L., and Medawar, P. B., Proc. Roy. Soc., B, 148, 58 (1954-55).

${ }^{15}$ Goswami, P., Dept. Exp. Path. and Cancer Res., Medical School, Leeds (personal communication). 